\title{
Quantitative Structure-Activity Relationships, Conformational Analyses and Computer Graphics Study of Triflumizole Analogs, Fungicidal $N$-(1-Imidazol-1-ylalkylidene)anilines
}

\author{
Akira Nakayama, Katsuyata Ikura, Kiyoshi KatsuUra, \\ Sho Hashimoto and Akira NaKata \\ Odawara Research Center, Nippon Soda Co., Ltd., Takada, Odawara 250-02, Japan
}

(Received June 24, 1988)

\begin{abstract}
Fungicidal activity of triflumizole, (E)-4-chloro- $\alpha, \alpha, \alpha$-trifluoro- $N$-(1-imidazol-1-yl-2propoxyethylidene)-o-toluidine, and its analogs against cucumber powdery mildew was analyzed quantitatively by using their physicochemical structural parameters and regression analysis. The result showed that steric, electronic and hydrophobic effects of substituents on the benzene ring were important for the fungicidal activity. The effects of substituents on the imino carbon were expressed by steric and hydrophobic parameters as well as indicator variables for $\alpha, \beta$-unsaturated and $\beta$-oxy structures. Conformational analyses and computer graphics were employed to study the mode of interaction of triflumizole with cytochrome $P-450$, the target enzyme of fungicidal azoles. An energy minimum structure of triflumizole was found to fit the cavity of cytochrome $P-450$ so as to block the oxidation of lanosterol, the ergosterol precursor. The result of regression analysis and the computer graphics model suggested that steric and hydrophobic properties of imidazole derivatives are important to inhibit the biosynthesis of ergosterol by antagonizing cytochrome $P$-450 oxidase.
\end{abstract}

\section{INTRODUCTION}

Triflumizole, $(E)$-4-chloro- $\alpha, \alpha, \alpha$-trifluoro- $N$ (1-imidazol-1-yl-2-propoxyethylidene) -o-toluidine (I) (Trifmine ${ }^{\circledR}$ ), is a new systemic fungicide for control of a wide range of diseases in many economically important crops. ${ }^{1,2)}$ Its antifungal properties ${ }^{3,4)}$ are similar to those of fungicides known as ergosterol biosynthesis inhibitors. ${ }^{5)}$

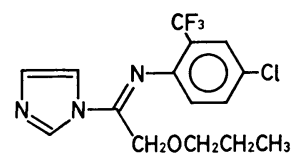

I

During the process to develop triflumizole, we synthesized a number of analogs and screened to optimize their antifungal properties as well as to reduce unfavorable effects on growth of crop plants. We also analyzed quantitative structure-activity relationships
(QSAR) to clarify the substituent effects of triflumizole analogs using physicochemical and structural parameters, finding that the fungicidal activity against cucumber powdery mildew is governed by steric, electronic and hydrophobic effects of substituents on the benzene ring, and steric, hydrophobic and hydrogen-bonding effects of side chain substituents at the imino carbon.

Inhibition of ergosterol biosynthesis by triflumizole and related azole fungicides is considered to emerge through inhibition of the cytochrome $P-450$ that catalyzes the $14 \alpha$ demethylation of 24-methylene-24,25-dihydrolanosterol, the ergosterol precursor. ${ }^{6,7)} \mathrm{We}$ examined the crystal structure of Pseudomonas cytochrome $P-450,{ }^{8)}$ a camphor oxidizing enzyme, as a model of the target enzyme of azole fungicides, since the structure of lanosterol demethylase has not been elucidated yet.

We employed a technique of computer 
graphics and conformational analysis to study the mode of interaction of a model enzyme with triflumizole. The study suggested that an energy-minimum structure of triflumizole easily fits into the active pocket of cytochrome $P-450$. This paper presents a model for the active structure of triflumizole at a target site based on the molecular modeling studies and the QSAR analyses of triflumizole and its related compounds.

\section{MATERIALS AND METHODS}

\section{Chemicals}

The fungicidal imidazoles used for QSAR analyses are listed in Tables 1 and 2.

They were mostly prepared by reaction of imidazole with appropriate $N$-phenylimidoyl chlorides which had been obtained by chlorination of corresponding amides (Fig. 1(a)). Some compounds were prepared by reaction of $N, N^{\prime}$ thionyldiimidazole with appropriate thioamides (Fig. 1(b)). Details of the synthetic methods have been described in the patents of this series of compounds. ${ }^{9-11)}$ Structures of the compounds were confirmed by ${ }^{1} \mathrm{H}-\mathrm{NMR}$ and IR spectra. Their melting points and refractive indices are listed in Tables 1 and 2.

\section{Fungicidal Activity and Phytotoxicity}

Cucumber seedlings (cv. Satsukimidori) were grown in unglazed pots filled with soil (dry weight: ca. $130 \mathrm{~g}$ per pot) containing some fertilizers. Each test chemical was dissolved with a small amount of acetone and diluted with water containing $0.02 \%$ spreader (Rabiden ${ }^{\circledR}$ SS: Mixture of $20 \%$ polyoxyethylene alkyl ester and $8 \%$ polyoxyethylene alkyl phenyl ether) to obtain desired concentrations. Solutions containing various amounts of a test compound ( $5 \mathrm{ml}$ per plant) were sprayed on the test plants of 1.5-leaf stage. One day after spraying, the cucumber seedlings were inoculated with the spore suspension $\left(10^{5} / \mathrm{ml}\right)$ of Sphaerotheca fuliginea and kept in a greenhouse at $20-24^{\circ} \mathrm{C}$.

The efficacy of each test compound was estimated 11 days after inoculation. Inhibition against emergence of powdery mildew on the cucumber leaves was graded by using the following indices; 0 (no colony), 1 (1-5 colonies), 2 (6-10 colonies), 3 (infested leaf area is less than or equal to $30 \%), 4 \quad(31-40 \%$ infested), 5 (41-50\% infested), $6 \quad(51-60 \%$ infested), $7 \quad(61-70 \%$ infested $), 8 \quad(71-80 \%$ infested), 9 (81-90\% infested), 10 (91-100\% infested). The inhibitory effect of fungicides was expressed by the percentage of control (PC) calculated by the following formula;

$$
\begin{aligned}
\mathrm{PC}= & \left(1-\frac{\text { average indices in the treated plot }}{\text { average indices in the control plot }}\right) \\
& \times 100
\end{aligned}
$$

$\mathrm{EC}_{90}$ values which represent a molar concentration required to inhibit infection by $90 \%$ of the control were determined graphically from the plot of the percentage control value against the concentration.

At the same time, plant-growth-regulating activity (PGR) was also assessed in the treated cucumber plant. The activity was classified into - (ordinary growth) to +++ (severe growth retardation).

\section{Quantitative Structure-Activity Relationships}

Structure-activity relationships of fungicidal imidazoles (II) were quantitatively studied by regression analysis using physicochemical and structural parameters. The fungicidal activity

(a)

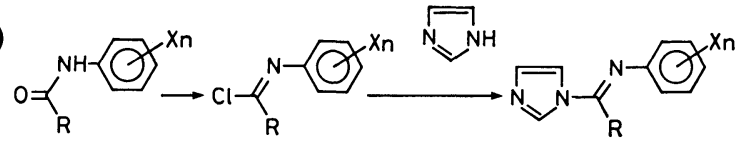

(b)

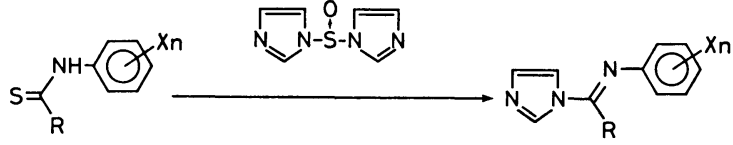

Fig. 1 Synthetic scheme of triflumizole and related fungicidal imidazoles. 
of the compounds varied with variations in the benzene ring ( $\mathrm{X}$ and $\mathrm{Y}$ ) as well as the imino carbon substituents $(Z)$. The effects of benzene-ring substituents were analyzed for a set of compounds where the substituent on imino carbon was benzyl. For the effects of the imino carbon substituents $(Z)$, a set of compounds, in which benzene-ring substituents are fixed to $2,4-\mathrm{Cl}_{2}$ or $2-\mathrm{CF}_{3}-4-\mathrm{Cl}$, were examined. The biological parameter, $\mathrm{pEC}_{90}$, was defined as the logarithm of $1 / \mathrm{EC}_{90}$.

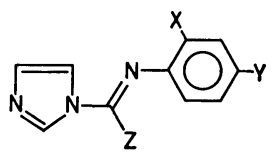

II

In order to evaluate the hydrophobicity of the benzene-ring moiety as properly as possible, the $\pi$ values of substituents in various solute systems were examined, and the value for the $N, N$-dimethylaniline system, $\pi$ (DMA), was selected as the one giving the best quality of correlation for the fungicidal activity. The $\pi$ (DMA) values were estimated by the method of Fujita et al. ${ }^{12,13)}$ according to Eq. (1).

$$
\begin{aligned}
\pi(\mathrm{DMA})= & 0.930 \pi(\text { monosubst. benzene }) \\
& +0.457 \sigma^{0}+0.162 E_{\mathrm{s}}^{\text {ortho }}-0.046
\end{aligned}
$$

In Eq. (1), $\sigma^{0}$ is the Taft electronic substituent constant $^{14,15)}$ of the benzene-ring substituents. For ortho substituents, the values of $\sigma_{\text {para }}^{0}$ were used for the estimation of $\pi(\mathrm{DMA})$. The $E_{\mathrm{s}}{ }^{\text {ortho }}$ represents the Taft-Kutter-Hansch steric substituent constant ${ }^{16,17)}$ of ortho substituent $\mathrm{X}$. The hydrophobicity of the substituent on imino carbon was estimated from the $\pi$ value of substituents in a mono-substituted benzene system, since the imino carbon is involved in a conjugated system similar to an aromatic ring. The $\pi$ values of the benzene system which are not listed in the literature were estimated by the additivity principle of Hansch \& Leo. ${ }^{18)}$ The estimation method is essentially the same as used in our previous studies. ${ }^{19,20)}$

Hammett's $\sigma^{21)}$ was selected to quantify the electronic effect of substituents on the benzene ring. For the steric properties of $\mathrm{X}, \mathrm{Y}$ and $\mathrm{Z}$, we examined various combinations of the STERIMOL parameters defined by Verloop et $a l .,{ }^{22,23)}$ and the modified indices developed by Iwamura et al. ${ }^{24-26)}$ and Mitsutake et al. ${ }^{27)}$ The indicator variables which take a value of 1.0 or zero depending on the presence or absence of certain structural features in the $Z$ moiety were considered for those such as $\alpha$ branching, $\beta$-oxygen and $\alpha, \beta$-unsaturation.

The level of significance of each parameter term was judged by the Student's $t$-test and that of regression equations by the $F$-test.

\section{Conformational Analysis and Molecular Modeling}

According to X-ray analysis, the geometry of $\mathrm{C}=\mathrm{N}$ double bond is in $E$-configuration, and the conformation of a propoxymethyl group is fully extended in triflumizole. The imidazole ring is nearly in coplanar with the imino group, whereas the benzene ring is twisted $c a$. $100^{\circ}$ to the imino group. Compound III (Fig. 2), a simplified model compound for triflumizole, was constructed from the crystal structure of triflumizole and was subjected to conformational analysis by means of semi-empirical molecular orbital calculations. The imidazole ring, the methoxymethyl group and the benzene ring of III were rotated around the bonds to the imino group in steps of $30^{\circ}$, and the total energy of the molecule was calculated for each conformation by using the AMPAC program ${ }^{28)}$ with AMl parameterization. ${ }^{29)}$

As a model of the target enzyme of triflumizole and its related fungicides, the crystal structure of Pseudomonas cytochrome P-450camphor complex was taken from the litera-

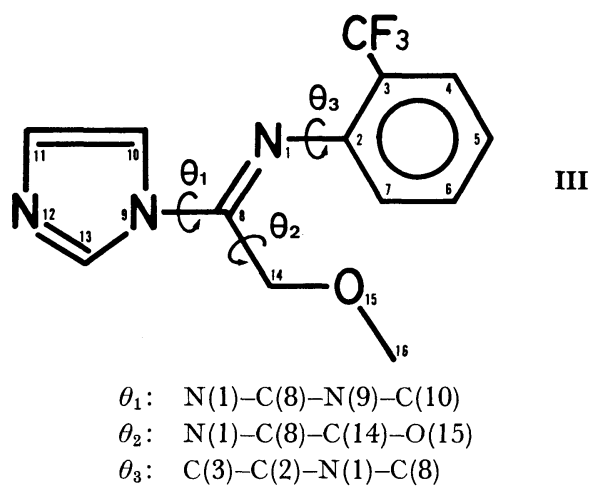

Fig. 2 Structure of model compound used in conformational analysis of triflumizole and definition of tortional angles $\left(\theta_{1}-\theta_{3}\right)$. 
Table 1 Fungicidal and PGR activities of triflumizole derivatives and physicochemical parameters used in Eqs. (2) and (3).

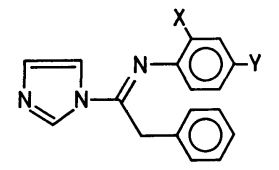

\begin{tabular}{|c|c|c|c|c|c|c|c|c|c|}
\hline \multirow{2}{*}{ No. } & \multirow{2}{*}{$\mathrm{X}$} & \multirow{2}{*}{$\mathrm{Y}$} & \multicolumn{3}{|c|}{ Parameters } & \multicolumn{2}{|c|}{$\mathrm{pEC}_{90}{ }^{\mathrm{a})}$} & \multirow{2}{*}{$\left.\mathrm{PGR}^{\mathrm{c}}\right)$} & \multirow{2}{*}{$\begin{array}{c}\text { Physical } \\
\text { properties } \\
{\left[\mathrm{mp}\left({ }^{\circ} \mathrm{C}\right) \text { or } n_{\mathrm{D}}\left({ }^{\circ} \mathrm{C}\right)\right]}\end{array}$} \\
\hline & & & $\sum \pi(\mathrm{DMA})$ & $\sum \sigma$ & $B_{5}^{\circ}$ & Obsd. & Calcd. ${ }^{\mathrm{b})}$ & & \\
\hline 1 & $\mathrm{H}$ & $\mathrm{H}$ & 0.00 & 0.00 & 2.00 & 3.42 & 3.36 & - & $95-97$ \\
\hline 2 & $\mathrm{~F}$ & $\mathrm{H}$ & 0.05 & 0.06 & 2.35 & 4.05 & 3.75 & - & $81-86$ \\
\hline 3 & $\mathrm{Cl}$ & $\mathrm{H}$ & 0.50 & 0.23 & 2.80 & 4.07 & 4.21 & - & $69.5-72$ \\
\hline 4 & $\mathrm{Br}$ & $\mathrm{H}$ & 0.59 & 0.23 & 2.95 & 3.83 & 4.26 & - & $1.6267(32)$ \\
\hline 5 & $\mathrm{Me}$ & $\mathrm{H}$ & 0.12 & -0.17 & 3.04 & 4.04 & 3.87 & - & $1.6005(22.5)$ \\
\hline 6 & $\mathrm{Et}$ & $\mathrm{H}$ & 0.53 & -0.15 & 4.17 & 3.16 & 3.12 & - & $1.6089(32.5)$ \\
\hline 7 & $\mathrm{OMe}$ & $\mathrm{H}$ & -0.27 & -0.27 & 4.07 & 3.16 & 2.91 & + & 96-98 \\
\hline 8 & $\mathrm{CF}_{3}$ & $\mathrm{H}$ & 0.43 & 0.54 & 3.61 & 4.12 & 4.11 & - & $1.5712(27)$ \\
\hline 9 & $\mathrm{CN}$ & $\mathrm{H}$ & -0.39 & 0.66 & 2.60 & 3.76 & 4.07 & - & $1.6182(27)$ \\
\hline 10 & COOMe & $\mathrm{H}$ & -0.09 & 0.45 & 4.36 & 2.73 & 2.92 & - & $1.5931(18.5)$ \\
\hline 11 & $\mathrm{Ph}$ & $\mathrm{H}$ & 0.87 & -0.01 & 4.11 & 2.93 & 3.41 & - & $117-120$ \\
\hline 12 & $\mathrm{H}$ & $\mathrm{F}$ & 0.16 & 0.06 & 2.00 & 3.57 & 3.45 & - & $87-88$ \\
\hline 13 & $\mathrm{H}$ & $\mathrm{Cl}$ & 0.74 & 0.23 & 2.00 & 4.37 & 3.75 & - & $69-75$ \\
\hline 14 & $\mathrm{H}$ & $\mathrm{Br}$ & 0.87 & 0.23 & 2.00 & 3.83 & 3.79 & - & $96-100$ \\
\hline 15 & $\mathrm{H}$ & $\mathrm{Me}$ & 0.42 & -0.17 & 2.00 & 3.14 & 3.42 & - & $85-86$ \\
\hline 16 & $\mathrm{H}$ & Et & 0.84 & -0.15 & 2.00 & 3.46 & 3.58 & - & $86-87$ \\
\hline 17 & $\mathrm{H}$ & $\mathrm{OMe}$ & -0.14 & -0.27 & 2.00 & 3.16 & 3.16 & - & $104-105$ \\
\hline 18 & $\mathrm{H}$ & $\mathrm{CF}_{3}$ & 1.02 & 0.54 & 2.00 & 3.64 & 4.02 & - & 109.3 \\
\hline 19 & $\mathrm{Cl}$ & $\mathrm{Cl}$ & 1.24 & 0.46 & 2.80 & 4.72 & 4.60 & + & $81-83$ \\
\hline 20 & $\mathrm{Br}$ & $\mathrm{Br}$ & 1.46 & 0.46 & 2.95 & 4.52 & 4.69 & - & $82-84$ \\
\hline 21 & $\mathrm{OMe}$ & $\mathrm{Cl}$ & 0.47 & -0.04 & 4.07 & 3.51 & 3.30 & - & $1.6042(23)$ \\
\hline 22 & $\mathrm{CF}_{3}$ & $\mathrm{Cl}$ & 1.17 & 0.77 & 3.61 & 5.07 & 4.50 & - & 79-81 \\
\hline 23 & $\mathrm{Me}$ & $\mathrm{Cl}$ & 0.86 & 0.06 & 3.04 & 4.39 & 4.26 & \pm & $72-73$ \\
\hline 24 & $\mathrm{Me}$ & $\mathrm{Me}$ & 0.54 & -0.34 & 3.04 & 3.76 & 3.92 & - & $76.5-78$ \\
\hline
\end{tabular}

a) Fungicidal activity $\left(\mathrm{pEC}_{90}\right)$ against cucumber powdery mildew.

b) Calculated by Eq. (3).

c) Plant-growth-regulating activity against cucumber.

ture. ${ }^{8,30)}$ In order to visualize the cavity of an active site, a camphor molecule bound to the enzyme as a substrate was taken away from the crystal structure, and the surface of the cavity was created for computer graphics representation by the method of Connolly. ${ }^{31,32)}$

Various conformers of triflumizole to give energy minimum conformations were constructed from the result of conformational analysis of model compound III. Then they were examined to dock into the active pocket of cytochrome $P-450$ by using a technique of computer graphics so as to generate an active form of triflumizole at a target site.
As a model of natural substrate of cytochrome $P-450$ in fungi, the structure of 24methylene-24,25-dihydrolanosterol, the ergosterol precursor, was constructed by using a model-building program "PRXBLD,", ${ }^{33}$ and was docked into the active pocket of cytochrome P-450. The computer graphics study was performed on a COMTEC DS-300 display and a FACOM M-340R computer by using a molecular-modeling software "MOLGRAPH." ${ }_{34)}$ 


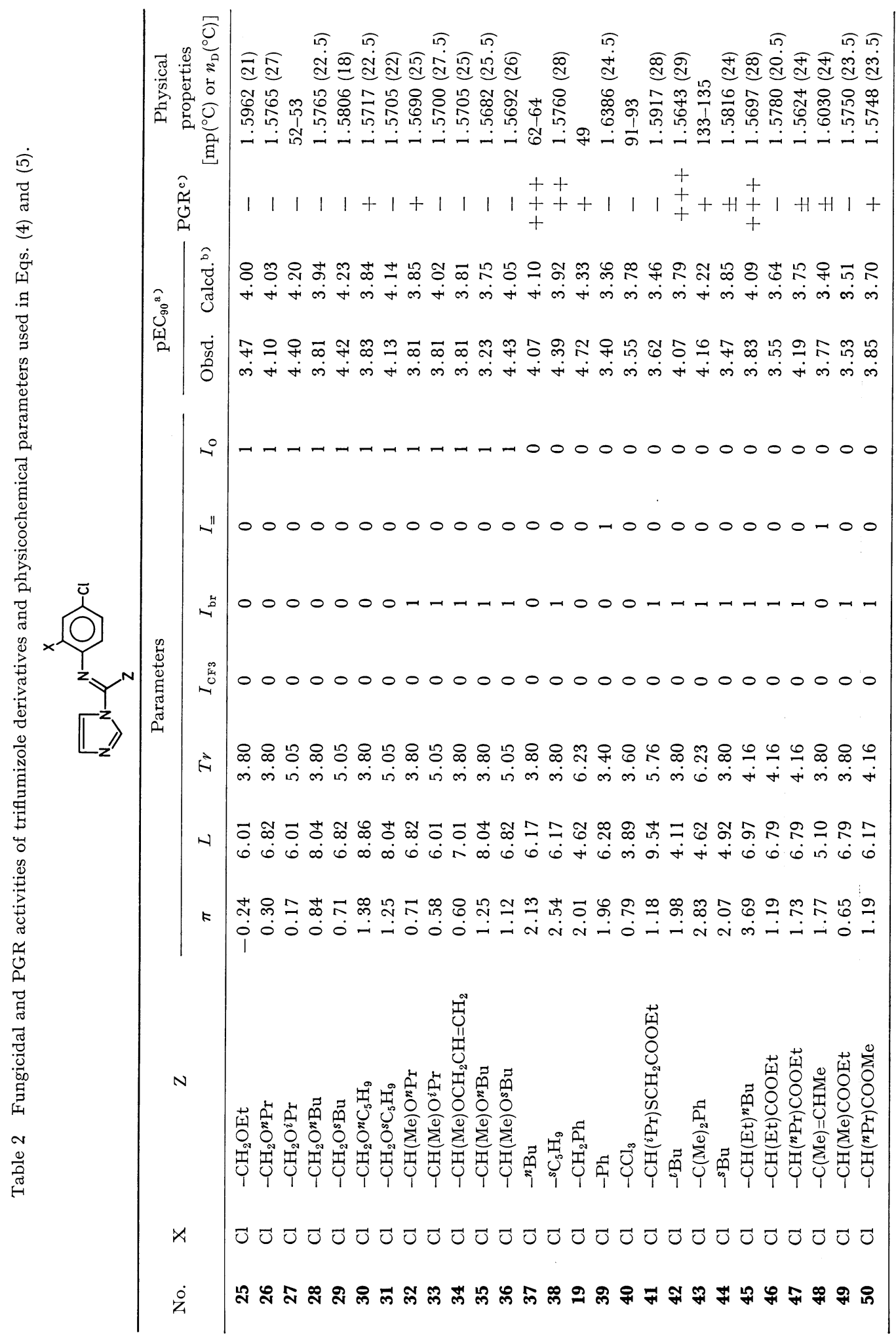




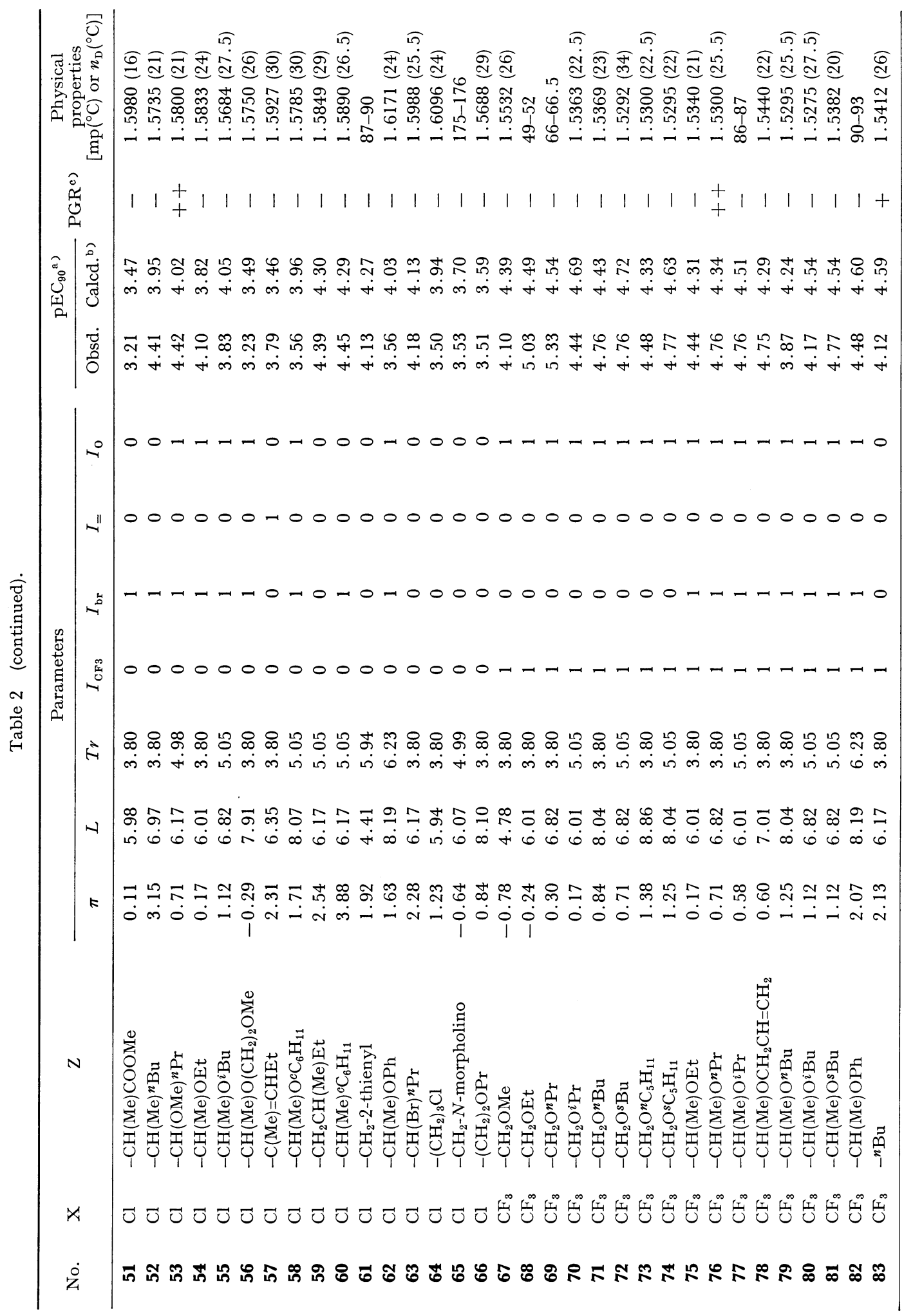




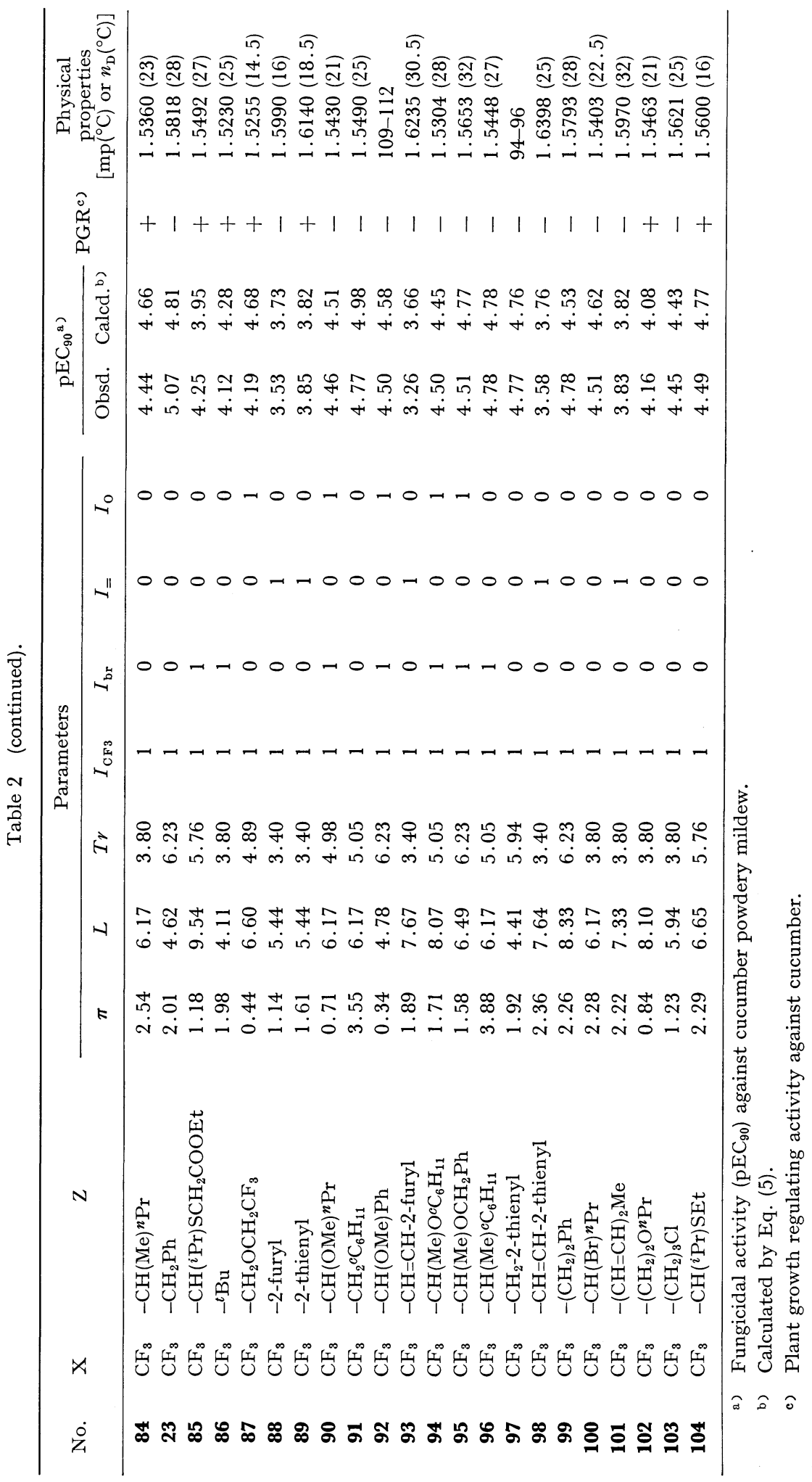




\section{RESULTS}

1. QSAR for Compounds Having Various Benzene-ring Substituents, $X$ and $Y$

For ortho substituted compounds (1-11) where $\mathrm{Y}$ is kept as hydrogen, Eq. (2) was obtained as the best quality of correlation.

$$
\begin{gathered}
\mathrm{pEC}_{90}=2.63 B_{5}{ }^{\circ}-0.67\left(B_{5}{ }^{\circ}\right)^{2}+1.49 \\
(1.40) \quad(0.31) \\
n=11, s=0.21, r=0.93, F=25.98
\end{gathered}
$$

In the above and subsequent equations, $n$ represents the number of compounds analyzed, $s$ the standard deviation, $r$ the multiple correlation coefficient and $F$ the $F$ value of the correlation. The figures in the parentheses are $95 \%$ confidence intervals.

In Eq. (2), $B_{5}^{\circ}$ is the STERIMOL width parameter which represents the maximum width of ortho substituent. Addition of Hammett's $\sigma$ and/or $\pi$ to Eq. (2) was also examined in regression analysis but was not significant at a level of $95 \%$ by the Student's $t$-test. The analysis of a larger compound set, including ortho-, para-, and 2,4-di-substituted compounds (1-24), however, indicated that $\pi$ and $\sigma$ terms were significant as shown in Eq. (3).

$$
\begin{aligned}
\operatorname{pEC}_{90}= & 0.36 \sum \pi(\mathrm{DMA})+0.55 \sum \sigma \\
& (0.30) \quad(0.46) \\
& +3.64 B_{5}{ }^{\circ}-0.62\left(B_{5}^{\circ}\right)^{2}-1.46 \\
& (1.61) \quad(0.26) \\
n= & 24, s=0.31, r=0.88, F=15.64
\end{aligned}
$$

In Eq. (3), $\sum \sigma$ is the summation of $\sigma_{\text {para }}$ values for $\mathrm{X}$ and $\mathrm{Y}$. For ortho substituents $\mathrm{X}, \sigma_{\mathrm{para}}$ was used. ${ }^{12}$ The $\sum \pi(\mathrm{DMA})$ values were obtained by the summation of $\pi(\mathrm{DMA})$ values estimated for $\mathrm{X}$ and $\mathrm{Y}$ in mono-substituted $N, N$-dimethylanilines. The $\pi$ values for substituted benzene and aniline series were also examined, but were less significant than

Table 3 Squared correlation matrix for variables used in Eq. (3).

\begin{tabular}{lccc}
\hline & $\sum \pi($ DMA $)$ & $\sum \sigma$ & $B_{5}{ }^{\circ}$ \\
\hline$\sum \sigma$ & 0.11 & & \\
$B_{5}{ }^{\circ}$ & 0.00 & 0.00 & \\
$\left(B_{5}{ }^{\circ}\right)^{2}$ & 0.00 & 0.00 & 0.99 \\
\hline
\end{tabular}

the $\pi$ (DMA). The level of significance of the parameters appearing in Eqs. (2) and (3) is above $95 \%$.

Table 1 shows the values of parameters, fungicidal and PGR activities, and the $\mathrm{pEC}_{90}$ values calculated by Eq. (3). The degree of correlation of the independent variables used in Eq. (3) is shown in Table 3.

\section{QSAR for Compounds Having Various Imino Substituents, $Z$}

Preliminary examinations suggested that the steric dimensions as well as the hydrophobicity

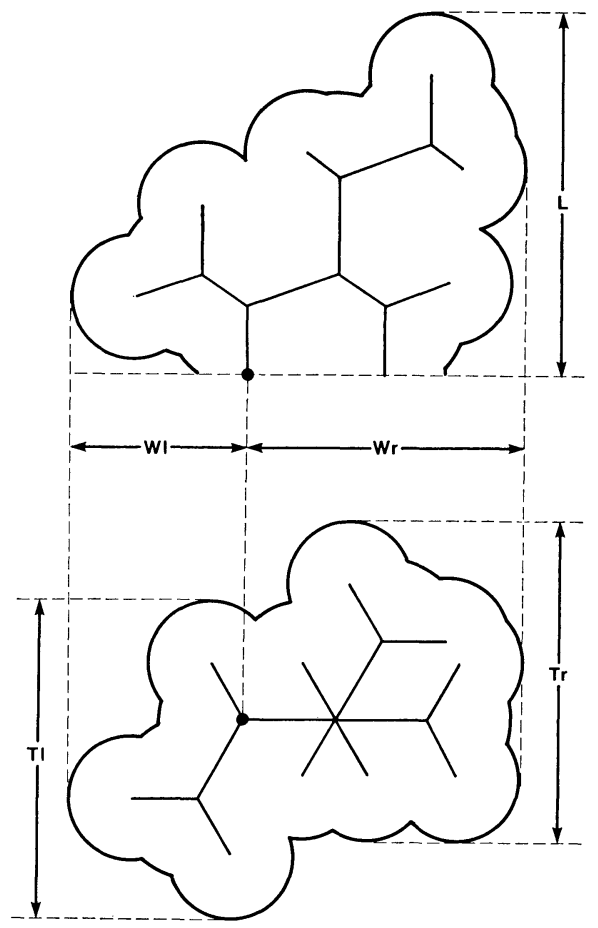

Fig. 3 STERIMOL-type parameters examined for imino substituents $(Z)$.

The substituent used as the model is 1,2-dimethylbutyl. $L$ is the length of a substituent along the bond axis that connects them to the rest of the molecule. $W r$ is the maximum width measured from the bond axis $(L)$ in the direction in which the longest chain of the substituents extends in the fully extended conformation, and $W l$ is the width in the opposite direction. $T r$ expresses the thickness of the right-hand part of the substituents and $T l$ that of the left-hand part. 
of the $\mathrm{Z}$ moiety may participate in determining fungicidal activity. We tested various combinations of STERIMOL-type parameters for steric effects to obtain Eq. (4), as one of the best correlation.

$$
\begin{aligned}
\mathrm{pEC}_{90}= & 0.20 \pi-0.10 L+0.07 T r \\
& (0.10) \quad(0.06) \quad(0.09) \\
& +0.49 I_{\mathrm{CF} 3}-0.24 I_{\mathrm{br}}-0.63 I_{=}= \\
& (0.14) \quad(0.16) \quad(0.26) \\
& +0.39 I_{\mathrm{o}}+3.98 \\
& (0.21) \\
n= & 82, s=0.31, r=0.80, F=18.86
\end{aligned}
$$

In this equation, $L$ is the STERIMOL length parameter of $\mathrm{Z} . \quad T r$ is a parameter which represents the thickness of substituent defined by Mitsutake et al. ${ }^{27)}$ The definition of $L$ and $T r$ is schematically shown in Fig. 3. $I_{\mathrm{CF} 3}, I_{\mathrm{br}}, I_{=}$and $I_{\mathrm{o}}$, are indicator variables. The $I_{\mathrm{CF} 3}$ takes 1.0 when the benzene-ring substituents are $4-\mathrm{Cl}-2-\mathrm{CF}_{3}$ and zero for 2,4$\mathrm{Cl}_{2}$. The $I_{\mathrm{br}}$ takes care of $\alpha$-branched alkyl and $\alpha$-branched $\alpha$-alkoxyalkyl structures such as $-\mathrm{CH}(\mathrm{R}) \mathrm{R}^{\prime}$ and $-\mathrm{CH}(\mathrm{R}) \mathrm{OR}^{\prime}$ where $\mathrm{R}$ is alkyl and $\mathrm{R}^{\prime}$ is alkyl or aryl. The $I_{=}$is for compounds where $Z$ is vinyl and aryl. The $I_{0}$ is for $\beta$-oxy structure such as $-\mathrm{CH}(\mathrm{R}) \mathrm{OR}^{\prime}$ and $-\mathrm{CH}_{2} \mathrm{OR}^{\prime}$.

The level of significance of the $T r$ term in Eq. (4) is only at a level of 90-95\%, and that of other parameters is above $99 \%$. An addition of $T r^{2}$ term did not afford any improvement, whereas an addition of $L^{2}$ term was significant, leading to Eq. (5).

$$
\begin{aligned}
\mathrm{pEC}_{90}= & 0.19 \pi+0.40 L-0.04 L^{2}+0.10 T r \\
& (0.09) \quad(0.47)(0.04)(0.09) \\
& +0.49 I_{\mathrm{C} \mathrm{F} 3}-0.26 I_{\mathrm{br}} \\
& (0.14)(0.15) \\
& -0.66 I_{=}=0.33 I_{\mathrm{o}}+2.29 \\
& (0.26) \quad(0.21) \\
n= & 82, s=0.30, r=0.81, F=17.88
\end{aligned}
$$

In Eq. (5), the level of significance of $L^{2}$ is above $95 \%$ whereas that of $L$ is above $90 \%$. The $\operatorname{Tr}$ term is now significant over 95\%. The internal correlations of independent variables used in Eqs. (4) and (5) are shown in Table 4 . Table 2 shows the values of param-

Table 4 Squared correlation matrix for variables used in Eqs. (4) and (5).

\begin{tabular}{lccccccc}
\hline & $\pi$ & $L$ & $L^{2}$ & $T r$ & $I_{\mathrm{CF} 3}$ & $I_{\mathrm{br}}$ & $I_{=}$ \\
\hline$L$ & 0.00 & & & & & & \\
$L^{2}$ & 0.00 & 0.98 & & & & & \\
$T r$ & 0.02 & 0.00 & 0.00 & & & & \\
$I_{\mathrm{CF} 3}$ & 0.00 & 0.00 & 0.00 & 0.01 & & & \\
$I_{\mathrm{br}}$ & 0.00 & 0.00 & 0.00 & 0.01 & 0.03 & & \\
$I_{=}$ & 0.03 & 0.00 & 0.00 & 0.12 & 0.01 & 0.09 & \\
$I_{0}$ & 0.35 & 0.09 & 0.08 & 0.01 & 0.01 & 0.07 & 0.12
\end{tabular}
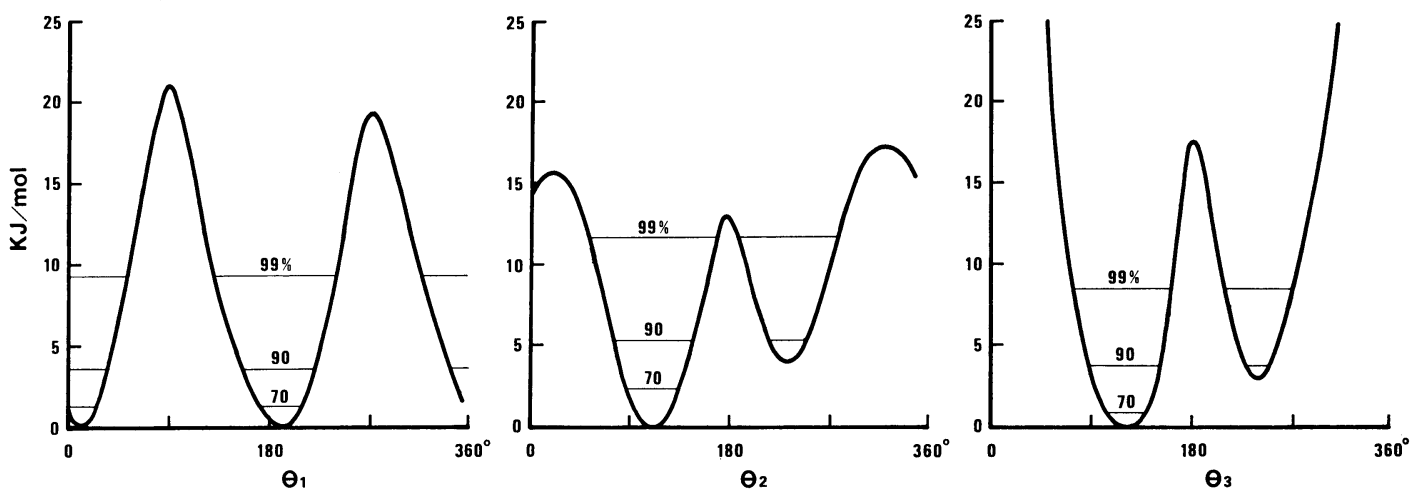

Fig. 4 Conformational energy of compound III for the rotation of $\theta_{1}, \theta_{2}$ and $\theta_{3}$.

Definition of tortional angles $\left(\theta_{1}-\theta_{3}\right)$ is shown in Fig. 2. Horizontal lines represent Boltzmann population levels of 70,90 and $99 \%$ at $37^{\circ} \mathrm{C}$. 
eters, fungicidal and PGR activities, and $\mathrm{pEC}_{90}$ values calculated by Eq. (5).

\section{Conformational Analysis and Molecular Modeling of Active Site}

The total energy of molecule III as a function of tortional angles $\left(\theta_{1}-\theta_{3}\right)$ (Fig. 2) was computed and is plotted in Fig. 4. For the rotation of the imidazole ring in III around the $\mathrm{C}(8)-\mathrm{N}(9)$ bond, two energy minima were observed at about $0^{\circ}$ and $180^{\circ}$ in terms of tortional angle $\theta_{1}$ where the imidazole ring is in coplanar with the imino group. The methoxymethyl group of III was stable when tortional angle $\theta_{2}$ was about $120^{\circ}$ or $240^{\circ}$. For the rotation of the benzene ring, molecule III was most stable when the benzene ring was twisted $\mathrm{ca} .120^{\circ}$ to the plane of the imino group.

The structure of triflumizole was examined in various combinations of $\theta_{1}, \theta_{2}$ and $\theta_{3}$ which gave energy minimum conformations of III. The structure of the $Z$-isomer of triflumizole was also examined similarly.

In the docking study of triflumizole into the active pocket of cytochrome $P-450$, the 3nitrogen atom of imidazole was placed at the position of the sixth ligand of porphyrin at an iron-nitrogen distance of $2.0 \AA$, and the plane of the imidazole ring was set perpendicularly to the plane of heme. The conformation of the propoxy group, which is more flexible than the backbone structure, was adjusted so as to fit the cavity of cytochrome P-450. The most reasonable conformation of triflumizole conceivable from the computer graphics was thus selected as a docking form, and was optimized in the AM1 procedure. In Table 5, the tortional parameters and total energy of triflumizole in docking conformation is compared with those of the crystal structure and the lowest energy conformer of triflumizole.

The Connolly's molecular surface of the cavity of cytochrome P-450 was drawn in a region above the heme group, the shape of the cavity looking like a "boot." The optimized

Table 5 Tortional angles and total energy of triflumizole in the binding form with cytochrome $P-450$, in crystal structure and in the lowest energy conformation.

\begin{tabular}{|c|c|c|c|c|}
\hline \multirow{2}{*}{$\begin{array}{l}\text { Tortional } \\
\text { angles }\end{array}$} & \multirow{2}{*}{$\begin{array}{l}\text { Defining atoms for } \\
\text { tortional angles }\end{array}$} & \multicolumn{3}{|c|}{ Values (deg.) } \\
\hline & & Binding form ${ }^{a}$ ) & $\begin{array}{l}\text { Crystal } \\
\text { structure }\end{array}$ & $\begin{array}{l}\text { Lowest energy } \\
\text { conformation }^{a}\end{array}$ \\
\hline$\theta_{1}$ & $\mathrm{~N}(1)-\mathrm{C}(8)-\mathrm{N}(9)-\mathrm{C}(10)$ & 4.7 & -9.9 & 3.3 \\
\hline$\theta_{2}$ & $\mathrm{~N}(1)-\mathrm{C}(8)-\mathrm{C}(14)-\mathrm{O}(15)$ & 124.7 & 128.3 & 126.5 \\
\hline$\theta_{3}$ & $\mathrm{C}(3)-\mathrm{C}(2)-\mathrm{N}(1)-\mathrm{C}(8)$ & 125.1 & 100.7 & 123.0 \\
\hline$\theta_{4}$ & $\mathrm{C}(8)-\mathrm{C}(14)-\mathrm{O}(15)-\mathrm{C}(16)$ & -174.6 & 169.2 & -177.7 \\
\hline$\theta_{5}$ & $\mathrm{C}(14)-\mathrm{O}(15)-\mathrm{C}(16)-\mathrm{C}(17)$ & 118.4 & -174.6 & -179.9 \\
\hline$\theta_{6}$ & $\mathrm{O}(15)-\mathrm{C}(16)-\mathrm{C}(17)-\mathrm{C}(18)$ & 177.7 & 177.7 & 178.4 \\
\hline \multicolumn{2}{|c|}{ Total energy $\left.(e V)^{b}\right)$} & -4895.978 & -4895.967 & -4896.007 \\
\hline
\end{tabular}

a) Values in the structure optimized by AM1.

b) Obtained by AM1 calculations. 

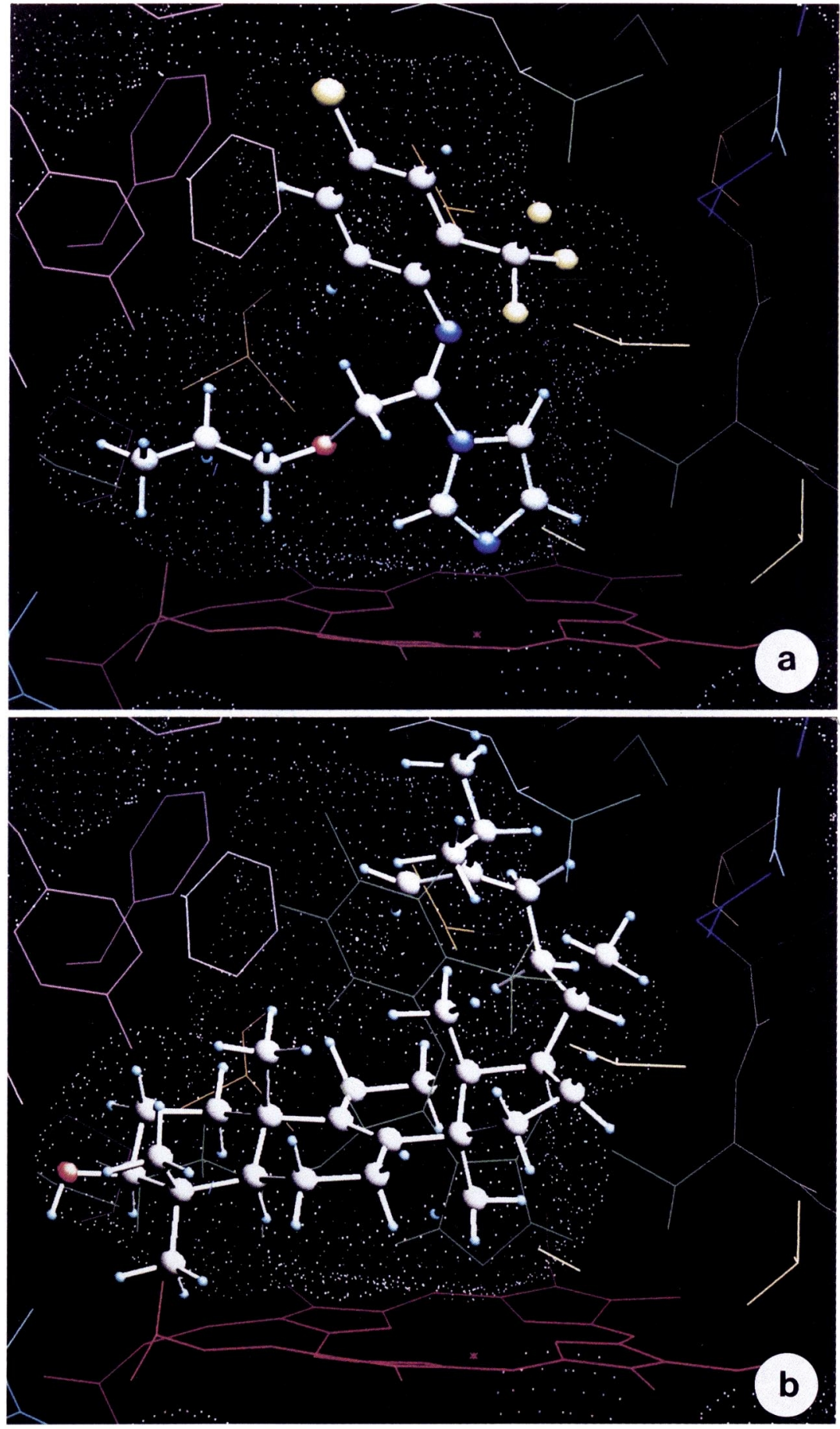

Fig. 5 Docking models of triflumizole (a) and lanosterol (b) in the active site of cytochrome P-450.

Dots around the molecules represent the Connolly's molecular surface of the active pocket of cytochrome $P-450$. The molecular surface was created as a water-accessible surface where the probe radius of a solvent was set to $1.5 \AA$. 
docking structure of triflumizole indicated that the propoxymethyl group is located at the "toe" and the benzene ring at the "ankle" of the cavity, as shown in Fig. 5(a). The benzene ring has to be twisted from the plane of the imino group in order to fit the pocket. The twisted structure approximately corresponds to the energy-minimum conformation with respect to the rotation of the benzene ring as indicated by conformational analysis. The position of 2-trifluoromethyl group on the benzene ring was found to locate in a hollow of the cavity surface in the docking conformation.

The $Z$-isomer of triflumizole was also examined to dock into the active pocket of cytochrome $P-450$, but it had a difficulty in fitting the cavity. The benzene ring of the $Z$-isomer was stuck out from the cavity surface when the imidazole and propoxymethyl group were superimposed onto those of the $E$-isomer.

A docking model of a natural substrate with cytochrome $P-450$ was investigated by using a molecular model of 24-methylene-24,25-dihydrolanosterol. A lanosterol molecule was placed in the active site according to the previous model of Marchington ${ }^{35)}$ and the position was adjusted by checking the interatomic distances between lanosterol and neighboring residues so as to maximize the overlap onto the cavity. The conformation of the flexible side chain was adjusted and optimized in the MM2 procedure ${ }^{36,37)}$ so that steric contact with enzyme residues was avoided. Fig. 5(b) shows the proposed model for the lanosterol molecule bound to cytochrome $P-450$ where the side chain moiety is located in a region above the plane of the steroid backbone and the $14 \alpha$-methyl group is placed at a position to be oxidized by the heme-oxygen complex. With this conformation in the pocket of cytochrome $P-450$, the side chain is extended to a site where the benzene ring of triflumizole is located and the steroid backbone is placed in a region in which the propoxymethyl group of triflumizole is bound.

\section{DISCUSSION}

In the QSAR for benzene-ring moiety, the steric parameter of an ortho substituent, $B_{5}{ }^{\circ}$, and its squared term were significant, as shown in Eqs. (2) and (3). This suggests that the size of the ortho substituent (X) is important for fungicidal activity and that the optimum value of $B_{5}{ }^{\circ}$ calculated by Eq. (3) is ca. $2.9 \AA$, which may correspond to the size of a steric interaction site in a receptor.

As shown in the docking model of triflumizole into the active pocket of cytochrome P-450, the ortho substituent interacts with a hollow of the cavity surface. A certain bulkiness may be required to fit the hollow, and the optimum size of the ortho substituent is represented by $B_{5}{ }^{\circ}$ parameter terms in regression analysis.

The steric parameters of $Z$ moiety, $L, L^{2}$ and $T r$, were also significant in Eq. (5), and the optimum value of $L$ was estimated to be ca. $5.3 \AA$. These steric features may correspond to the size and the shape of an interaction site on the target enzyme with the $Z$ moiety. The docking model of triflumizole in cytochrome $P-450$ suggests that the length of the $Z$ moiety corresponds to the depth of the pocket along the direction from "heel" to "toe" of the cavity, and that the width or the thickness of the $Z$ moiety corresponds to the diameter of the pocket. A schematic representation of the steric interaction site of triflumizole derivatives in cytochrome $P-450$ is drawn in Fig. 6 from the results shown above.

The hydrophobic parameters of the benzenering moiety and $Z$ substituent were significant in QSAR analysis, and the positive sign of

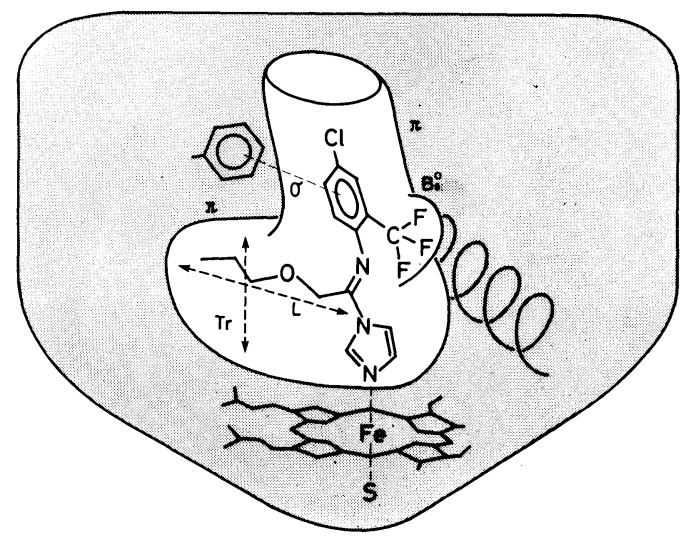

Fig. 6 Schematic representation of an interaction site of triflumizole in cytochrome P-450. 
their coefficient indicates that the higher the hydrophobicity, the higher the activity. The environment of the substrate pocket of Pseudomonas cytochrome $P-450$ is known to be hydrophobic. $^{8)}$ The heme itself provides a hydrophobic surface, and some hydrophobic residues around the pocket such as Leu 244 and Val 295 are also important for binding with a substrate. When the substrate is replaced by an inhibitor at the active pocket, hydrophobic interaction between the inhibitor and the surface of the pocket should be also important and hydrophobic substituents on triflumizole derivatives may strengthen the binding to the enzyme as suggested by the $\pi$ terms.

The QSAR for the benzene-ring moiety indicated that substituents with electron withdrawing properties are favorable to the activity. Such electronic effects may represent the reactivity or stability of the molecule as well as the electrostatic interaction between the molecule and the receptor. The rate of oxidative degradation or metabolism may be reduced by the electron withdrawing power of the substituents on the benzene ring. In the interaction model of triflumizole with cytochrome P-450 shown in Fig. 5, the benzene ring of triflumizole is surrounded by aromatic residues such as Phe 87 and Phe 98. We speculate that the electron deficient benzenering system of triflumizole may interact with the aromatic residues by means of electronic attractions besides hydrophobic binding.

Among the indicator variables appearing in Eqs. (4) and (5), the significance of $I_{0}$ term indicates that $\beta$-oxy structure is favorable for higher activity. A hydrogen-bonding interaction between $\beta$-oxygen and acidic hydrogen on the receptor site is suggested. In the computer graphics representation of triflumizole in cytochrome $P$-450, however, such a hydrogen bonding was not clearly observed. The conformational flexibility of $Z$ moiety should be reduced in compounds having an $\alpha$-branched or $\alpha, \beta$-unsaturated structure. The $I_{\mathrm{br}}$ and $I=$ terms in Eqs. (4) and (5) may indicate that such structural features weaken the interaction with the enzyme in terms of conformational restrictions.

The configuration of triflumizole with re- spect to the $\mathrm{C}=\mathrm{N}$ double bond was previously assigned to $E$ by means of X-ray crystallography and NMR spectra. The $E$-isomer was more easily docked in the active site than the $Z$-isomer. In the structure-activity study of styryltriazole fungicides by Funaki et al. ${ }^{38,39)}$ the $E$-isomers were more active than the corresponding $Z$-isomers against powdery mildew and brown rust. Their result may coincide with our model of active structure.

Besides geometrical configurations around the $\mathrm{C}=\mathrm{N}$ double bond, the conformation of triflumizole is also important for binding with a target enzyme. The conformational analysis on the model compound of triflumizole suggested that rotations of three substituents on the imino group are restricted within certain ranges in terms of tortional angles $\theta_{1}, \theta_{2}$ and $\theta_{3}$ as shown in Fig. 4. The structure of triflumizole in the docking model is coincided with the one of the energy minimum conformations, and its total energy is comparable to the energy in the lowest energy conformation (Table 5). A notable difference in conformation between the docking form and the lowest energy structure is only in the flexible propoxy group. The STERIMOLtype parameters of $Z$ substituent were estimated for fully extended conformation, while the docking form of triflumizole is slightly twisted in the $Z$ moiety. QSAR analysis using the parameters in active conformation as suggested by computer graphics might be more reliable. Nevertheless, the fact that the results of QSAR analysis conform with a model for interaction drawn by computer graphics indicates that structure-activity profiles of triflumizole derivatives reflect structural requirements at a primary active site of azole fungicides.

PGR activities of the compounds analyzed are listed in Tables 1 and 2 in terms of relative score. Potency of PGR activity is affected by variations in structure of the $Z$ moiety than by variations in benzene-ring substituents (X and Y). Although PGR activity was not analyzed quantitatively, an introduction of $\beta$-oxygen into the $Z$ moiety generally decreases PGR activity. PGR effect of fungicidal azoles has been considered due to inhibition of gibberellin biosynthesis in plants involving 
oxidation of kaurene catalyzed by cytochrome $P-450 .{ }^{40)}$ Selective inhibition of cytochrome $P-450$ systems either in fungi or in plants should be important for the property of fungicides to be used for plant protection. Triflumizole, which has $2-\mathrm{CF}_{3}-4-\mathrm{Cl}$ on the benzene ring and a propoxymethyl group as $Z$ moiety, has been selected as a commercial fungicide because of its potent antifungal activity and its negligible PGR effect at practical concentrations. Further studies on structural differences in cytochrome $P-450$ in various biological systems will help to understand the details of interactions between the enzyme and inhibitors.

\section{ACKNOWLEDGMENTS}

The authors wish to express their thanks to Professor Toshio Fujita of Kyoto University for his invaluable suggestions. A modified version of the STERIMOL program was kindly provided by Dr. Hajime Iwamura and Mr. Masaaki Asao of Kyoto University. The authors also thank Mr. Izumi Kumita and Dr. Shinsuke Sano for their encouragement and suggestions. Thanks are also given to $\mathrm{Mr}$. Shigeru Kojima for the preparation of chemicals, and Mr. Hiroyasu Hosokawa for his skillful work in bioassay. An author (A. Nakayama) is indebted to Dr. W. Graham Richards of Oxford University for his invaluable suggestions and discussions on the computational studies.

\section{REFERENCES}

1) A. Nakata, K. Ikura \& A. Wakai: Abstr. 5th Int. Congr. Pestic. Chem., IIb 9, 1982

2) S. Hashimoto, A. Murakami, M. Mizuno, H. Nishikawa \& Y. Yasuda: Ann. Phytopathol. Soc. Jpn. 49, 421 (1983)

3) S. Hashimoto, S. Sano, A. Murakami, M. Mizuno, H. Nishikawa \& Y. Yasuda: Ann. Phytopathol. Soc. Jpn. 52, 599 (1986)

4) S. Hashimoto, S. Sano \& Y. Morishima: Proc. Bordeaux Mixture Centen. Meet., pp. 277-280, 1985

5) H. Buchenauer: Proc. Br. Crop Prot. Conf., pp. 699-711, 1977

6) T. E. Wiggins \& B. C. Baldwin: Pestic. Sci. 15, 206 (1984)

7) M. J. Henry \& H. D. Sisler: Pestic. Biochem. Physiol. 22, 262 (1984)

8) T. L. Poulos, B. C. Finzel, I. C. Gunsalus, G. C. Wagner \& J. Kraut: J. Biol. Chem. 260, 16122 (1985)

9) K. Ikura, K. Katsuura \& M. Kataoka (Nippon
Soda Co., Ltd.): Jpn. Kokai Tokkyo Koho JP52-39674 (1977)

10) K. Ikura, K. Katsuura \& M. Kataoka (Nippon Soda Co., Ltd.): Jpn. Kokai Tokkyo Koho JP53-135975 (1978)

11) K. Ikura, K. Katsuura, A. Nakata \& M. Mizuno (Nippon Soda Co., Ltd.): Jpn. Kokai Tokkyo Koho JP54-119462 (1979)

12) T. Fujita: Prog. Phys. Org. Chem. 14, 75 (1983)

13) T. Sotomatsu, Y. Murata \& T. Fujita: Abstr. 15th Symp. Structure-Activity Relationships, Tokyo, No. 7H13, 1987

14) R. W. Taft, Jr.: J. Phys. Chem. 64, 1805 (1960)

15) O. Exner: "Advances in Liner Free Energy Relationships," ed. by B. Chapman \& T. Shorter, Plenum Press, London, pp. 1-69, 1972

16) R. W. Taft, Jr.: "Steric Effects in Organic Chemistry," ed. by M. S. Newman, John Wiley \& Sons, New York, pp. 556-675, 1956

17) S. H. Unger \& C. Hansch: Prog. Phys. Org. Chem. 12, 91 (1976)

18) C. Hansch \& A. Leo: "Substituent Constants for Correlation Analysis in Chemistry and Biology," John Wiley \& Sons, New York, 1979

19) A. Nakayama, H. Iwamura \& T. Fujita: $J$. Med. Chem. 27, 1493 (1984)

20) A. Nakayama, H. Iwamura, A. Niwa, Y. Nakagawa \& T. Fujita: J. Agric. Food Chem. 33, 1034 (1985)

21) L. P. Hammett: "Physical Organic Chemistry," 2nd ed., McGraw-Hill, New York, 1970

22) A. Verloop, W. Hoogenstraarten \& J. Tipker: "Drug Design," ed. by E. J. Ariens, Vol. 7, Academic Press, New York, pp. 165-206, 1976

23) A. Verloop: "Pesticide Chemistry," ed. by J. Miyamoto \& P. C. Kearney, Vol. 1, Pergamon Press, Oxford, pp. 339-344, 1983

24) H. Iwamura: J. Med. Chem. 23, 308 (1980)

25) H. Iwamura: J. Med. Chem. 24, 572 (1981)

26) H. Iwamura, T. Fujita, S. Koyama, K. Koshimizu \& Z. Kumazawa: Phytochemistry 19, 1309 (1980)

27) K. Mitsutake, H. Iwamura, R. Shimizu \& T. Fujita: J. Agric. Food Chem. 34, 725 (1986)

28) J. J. P. Stewart: Quantum Chem. Program Exch., No. 523, 1987

29) M. J. S. Dewar, E. G. Zoebisch, E. F. Healy \& J. J. P. Stewart: J. Am. Chem. Soc. 107, 3902 (1985)

30) The X-ray structure of Pseudomonas cytochrome $P$-450cam was obtained from the Brookhaven Protein Data Bank.

31) M. L. Connolly: Science 221, 709 (1983)

32) M. L. Connolly: Quantum Chem. Program Exch., No. 429, 1983

33) PRXBLD is an "approximate model builder" 
that uses molecular mechanics techniques developed by Molecular Design Limited, Hayward.

34) MOLGRAPH is a three-dimensional molecular modeling program developed by Daikin Industries Limited, Tokyo.

35) A. F. Marchington: "Pesticide Synthesis through Rational Approaches," ed. by P.S. Magee, G. K. Kohn \& J. J. Menn, ACS Symposium Series 255, pp. 173-183, 1984

36) N. L. Allinger: J. Am. Chem. Soc. 99, 8127 (1977)

37) N. L. Allinger \& Y. H. Yuh: Quantum Chem. Program Exch., No. 395, 1980

38) Y. Funaki, Y. Ishiguri, T. Kato \& S. Tanaka: J. Pesticide Sci. 9, 229 (1984)

39) Y. Funaki, Y. Ishiguri, T. Kato \& S. Tanaka: "Pesticide Chemistry," ed. by J. Miyamoto \& P. C. Kearney, Vol. 1, Pergamon Press, Oxford, pp. 309-314, 1983

40) H. Takano, Y. Oguri \& T. Kato: J. Pesticide Sci. 11, 373 (1986)
要 約

Triflumizole 類縁体殺菌活性 $N$-(1-imidazol-1ylalkylidene) anilines の定量的構造活性相関,

コンホメーション解析およびコンピュータ・グ ラフィクス

中山 章, 井倉勝弥太, 勝浦喜代志 橋本 章, 中田 昭

イミダゾニル系殺菌剤 triflumizole [( $E)$-4-chloro- $\alpha, \alpha, \alpha$ trifluoro- $N$-(1-imidazol-1-yl-2-propoxyethylidene)-o-toluidine] およびその類縁体のキュウリうどんこ病菌に対す る殺菌活性をポット試験により検定し，その構造活性相 関を物理化学的パラメータを用いて重回帰分析により解 析した. ベンゼン環上の置換基は，疎水性が高く電子吸 引性が大きいほど活性が高く，また，オルト位の置換基 には最適な高高さが存在することが示された。イミノ基 の炭素上の置換基は，疎水性や大きさ，形状とともに， 水素結合性や枝分れの有無などが活性発現上重要である ことが示唆された. 一方，アゾール系殺菌剂の作用点と 考えられるチトクロームP-450 中での triflumizole の活 性構造について, コンホメーション解析およびコンピュ ータ・グラフィクスの手法で解析した結果, triflumizole は安定なコンホメーションでチトクローム P-450 の活 性中心と結合し，エルゴステロールの生合成を阻害する ことが推定された。 